\title{
Innovation Platform for Catalyzing Access to Seed of Improved Legume Varieties to Smallholder Farmers
}

\author{
Essegbemon Akpo, Chris O. Ojiewo, Issoufou Kapran, \\ Lucky O. Omoigui, Agathe Diama, and Rajeev K. Varshney
}

\begin{abstract}
Innovation platform resolves systemic problems and unlock opportunities for farmers and other stakeholders along commodity value chains. It brokers change in a wide variety of areas involving technological barriers for increased on-farm genetic gains, financial services and privileges for smooth running of seed business and other farming activities, social change and gender equality in society, new commodity market opportunities, increased interactions between stakeholders, e-services for increased crop productivity and production, sustainability of seed production and delivery systems through a variety of stakeholders for various seed classes.
\end{abstract}

\section{Keywords}

Improved legume variety - Productivity of smallholder farming - Systemic change $\cdot$ Innovation platform $\cdot$ Sub-Saharan Africa and South Asia

E. Akpo $(\varangle) \cdot$ C. O. Ojiewo

International Crops Research Institute for the Semi-Arid Tropics (ICRISAT), Nairobi, Kenya e-mail: e.akpo@cgiar.org; akpo.essegbemon@gmail.com

I. Kapran · A. Diama

RP-WCA, ICRISAT, Bamako, Mali

L. O. Omoigui

International Institute of Tropical Agriculture, Kano, Nigeria

R. K. Varshney

Research Program - Genetic Gains, International Crops Research Institute for the Semi-Arid Tropics (ICRISAT), Patancheru, India

(C) The Author(s) 2021

E. Akpo et al. (eds.), Enhancing Smallholder Farmers' Access to Seed of

Improved Legume Varieties Through Multi-Stakeholder Platforms,

https://doi.org/10.1007/978-981-15-8014-7_14 


\subsection{Introduction}

The power of innovation platform to solve systemic problems and unlock opportunities for millions of farmers and other stakeholders cannot be over-emphasized (Adekunle et al. 2013). The various contributions in this book have proved to light various areas where innovation platforms brokered social change and various kind of innovations. Ultimately, it permitted to millions of farmers, including the resource-limited farmers in remote areas, to access seed, other inputs, financial services and subsequently improved productivity and production of legume crops in sub-Saharan Africa and South Asia (India). The following sections provide a glance of those areas reported in this book in the different countries.

\subsection{Breaking the Technological Barriers to Increase On-Farm Genetic Gains}

The example of groundnut in Burkina Faso as reported by Miningou et al. (this volume) is illustrative. Through the innovation platform (IP), the groundnut breeders in the country took the opportunity to engage with agricultural service staff, NGOs (e.g. FERT) as platform members to help farmers on the ground. Before the IP initiation, the staff of those organizations were not trained on groundnut production practices apart from the basic courses they took in agricultural schools. After being brought in the platform, they got the opportunity to learn about good practices of groundnut production and the comparative advantages of improved varieties (early and medium maturity, and other major traits including disease resistance like rosette). The knowledge the agricultural service staff and the NGOs workers gained helped them to promote the improved varieties of groundnut, train community farmers to measure the size of their farms, impart skills to farmers to monitor their daily activities and provide various other advisory supports as per farmer need. As results of the tailored support received through the platform interventions, farmers in the target areas have more than double their previous yields from $500-700 \mathrm{~kg} / \mathrm{ha}$ to $1200-1500 \mathrm{~kg} / \mathrm{ha}$. In India, there was a change in the knowledge of varieties by farmers from older than 20 years chickpea varieties (e.g. KWR 108 and Radhey) to new and recently released varieties (e.g. Kabuli: Shubhra, Ujjawal; Desi: JG 14, JAKI 9218, RVG 202, JG 16, RVG 203) (Sah et al. this volume). This is a good starting point for increased variety turnover in India in the near future. In Mali, the IP also facilitated weekly seed fairs to expose more farmers to new varieties and enhance cowpea productivity in the target geographies (Kouyate et al., this volume). These experiences prove that IP constitutes an effective mechanism to break technology barriers for enhanced on-farm productivity and production of groundnut, chickpea and cowpea in various countries. 


\subsection{Unlocking Financial Services and Privileges for Smooth Running of Seed Business and Farming Activities}

In Ghana, groundnut farmers have challenges of getting financial resources to plough their fields and buy the needed inputs such as seed and herbicides (Puozaa et al. this volume). In the same communities where farmers face tough difficulty to access finance services, there are rural banks, savings and loans institutions. The main problem is the high cost of borrowing and demand for collateral that discard or constitute a disincentive to most farmers and most importantly, small scale farmers. The perceptions of these financial institutions that the agricultural sector is a very risky business hikes the interest rates applied that go up to about $40 \%$ per annum for farmers or someone venturing in agriculture. Thanks to the IP interventions, this challenge of funding has been effectively addressed. The platform members were introduced to the idea of the Village Savings and Loans Association (VSLA) concept. The VSLA is a self-help microfinance initiative where group members put money together through weekly savings for a period of nine months. The savings of GHS 203.00 (equivalent to US\$39) per member over the period are collected. Members are also allowed to buy shares at GHS 1.00 (US\$0.19) per share. Each member is allowed to buy a maximum of 5 shares per week. With the VSLA initiative, platform members were able to borrow money from the savings to attend their farming activities and their secondary income generating activities. The borrowed money is paid back with a maximum interest rate of $10 \%$ per annum. This interest rate is very low compared to the ones of the financial industry which vary between $25 \%$ and $40 \%$ per annum. This VSLA strategy that the innovation platform has facilitated proved to relieve farmers of financial burdens associated with high interest rates from banks and other finance institutions. Thanks to the platform, it is no longer a headache for farmers in the target communities to smoothly implement farming activities timely, and subsequent productivity and production enhancement of groundnut in Ghana.

\subsection{Inducing Social Change and Gender Equality in Society}

Thanks to the platform interventions in Burkina Faso, women have equal access to seed of improved cowpea varieties compared to men (Batiéno et al. this volume). Women saw their capacity built on good agricultural practices for cowpea as they took part in most training sections organized. Women's access to extension services has improved as well. Because of these enhanced capacities, women are no longer obliged to seek advice from their husband before buying seed of improved varieties. Before the platform intervention, women always consult their husband before getting a certain variety. The knowledge women gained from the various platform activities gave them a kind of independence and the power to confidently make their own decision. The observed change due to the platform activities has also positively impacted the women producing chickpea in India (Sah et al. this volume). Reports by the authors indicated that the involvement of women in seed systems activities 
enhanced to $17 \%$ against the almost no involvement at the start of the platform interventions. In Mali for cowpea, the rural exodus involving the youth who go for gold mining sites and the major cities has decreased considerably (Kouyate et al. this volume). The improvement of their standard of living is the main leading factor. Motorcycles have replaced bicycles as the main means of transportation for most young farm entrepreneurs. These recorded changes are critical changes in society, especially in the area of gender integration, equality, empowerment and youth engagement in agriculture.

\subsection{Access to New Commodity Market Opportunities}

Chickpea farmers in various communities were facing major problems with respect to grain market in Ethiopia (Chichaybelu et al. this volume). There was a poorly coordinated supply chain that links the producers and the off-takers. As a consequence, this increases the transaction costs for farmers and therefore lowers the share of the consumer price that small producers finally receive. The absence of efficient mechanism for delivering market information to the farmers and traders at local markets regarding seasonal prices, demand, and quality requirements by different markets outlets and the lack of a well-established system of grades and standards are reported to be the major threats to chickpea marketing systems. Thanks to the platform interventions, recent reports indicate a significant improvement and competitiveness of the Ethiopian chickpea in both local and export markets. In the same vein, successful interventions by Ethiopian research institute and the Ministry of Agriculture enhanced the chickpea seed marketing. The platform linked seed producer associations to various seed buyers including the regional bureaus of agriculture, NGOs and other organizations that distribute seed of improved varieties to the farmers. Seed producers nowadays have better market and sell their seed with a minimum of $15 \%$ higher premium price over actual grain price most farmers receive. In Nigeria, Iorlamen et al. (this volume) reported that key factor to successful and sustained adoption of yield enhancing agricultural technologies was an assured market, through which farmers can sell their cowpea in Nigeria. Likewise, farmers' awareness of price information played a major role in their bargaining power and the competitiveness of their produce in business transactions. Similar experiences have been observed with groundnut farmers in Nigeria (Mohammed et al. this volume).

\subsection{Effective Seed Delivery to Smallholder Farmers Requires Increased Interactions Between Stakeholders}

The experience from the cowpea IP in Burkina Faso concluded that the observed success of the platform largely depended on the harmonious interactions among the stakeholders (Yirzagla et al. this volume). The sustainability of the interventions will require a number of actions that fall into close interactions between various 
actors. According to Yirzagla et al. (this volume), these include (1) well-defined and coordinated roles for all stakeholders; (2) the existence of synergy among all actors but also their specific interests to benefit from platform achievements; (3) the mutual trust and understanding among various stakeholders complementing one another; (4) good leadership and facilitation skills by the platform stakeholders and the facilitating institution; (5) due attention to and managing of perceptions, competing interests, eventual risks, availability and access to common resources, among the diverse stakeholders; (6) the devotion of individuals and groups to implement the platform activities and finally (7) reliable information, communication, documentation, learning and sharing of best practices.

\subsection{Expansion of E-Services for Increased Crop Productivity and Production}

The members of the IP growing groundnut in Mali have used the social network SENEKELA of Orange mobile telecom company in Mali to get frequent weather reports, and early warning systems (Sako et al. this volume). This helps them to avoid crops failure and limits risks related to natural catastrophes. The farmer cooperatives which are part of the platform also exchange information with one another on the social networks to find a buyer for the surplus of their harvest. Many platform members have managed to open savings accounts. These breakthroughs observed within farming communities have significantly impacted farmer livelihood and prove the power of innovation platform to broker systemic and sustainable innovations et bring communities out of poverty.

\subsection{Enhancing Sustainability of Seed Production and Delivery Systems Through a Variety of Stakeholders Involved in Various Classes of Seeds}

The groundnut innovation platform established in Tanzania brought together a wide variety of actors each bringing a different expertise (Alex et al. this volume). The different categories included groundnut researchers, extension workers, private seed companies, public seed company (the Agricultural Seed Agency), media people, farmer research groups, policy makers, individual seed entrepreneurs, grain traders and processors, financial institutions, agro dealers, NGOs, local government authorities, seed regulatory authorities, transporters and agricultural marketing cooperatives. While the focus of groundnut researchers is breeder seed, public seed company and other private seed companies are in charge of foundation seed production and marketing. Private seed companies are responsible for certified seed production. Farmer research groups, individual seed entrepreneurs are producing quality declared seed that they spread through remote communities across agro-ecological zones of groundnut production in Tanzania. Efforts are made to strengthen the 
linkages between these stakeholders. Grain off-takers are now brought on-board to secure market outlets for farmers.

\subsection{Conclusion}

The wide diversity of services that innovation platforms facilitate to farmers in addition to quality seed of legume crops proves that systemic problems can be solved, and opportunities can be effectively unlocked for farmers and other stakeholders along the commodity value chains. The cross-case analysis highlighted the overall outcomes of the various experiences and pinpoints some of the areas where the interventions could have brought more benefits and at scale (Monyo et al. this volume). We recommend innovation platforms as a strong tool for research and development interventions to harness opportunities for communities in the semi-arid areas. Smart partnerships among support organizations and value chain actors will help to cut cost involved in managing innovation platforms to make them sustainable.

\section{References}

Adekunle AA, Fatunbi AO, Buruchara R, Nyamwaro S (2013) Integrated Agricultural Research for Development: from concept to practice. Forum for Agricultural Research in Africa (FARA), Accra, Ghana

Alex G, Mponda OK, Akpo E, Monyo E, Nzunda J, Daudi H, Joseph A, Mlimbila HG, Ndolelwa D, Mkandawile C (this volume) Groundnut seed production and distribution through multistakeholder platforms in Southern Region of Tanzania. In: Akpo E, Ojiewo CO, Kapran I, Omoigui LO, Diama A, Varshney RK (eds) Enhancing smallholder farmers' access to seed of improved legume varieties through multi-stakeholder platforms. Springer, Singapore

Batiéno BJ, Poda SL, Barry S, Compaore E, Zongo H, Sidibe H, Gnankambary K, Sanou OA, Neya BJ (this volume) Cowpea innovation platform interventions and achievements in TL III project in Burkina Faso. In: Akpo E, Ojiewo CO, Kapran I, Omoigui LO, Diama A, Varshney RK (eds) Enhancing smallholder farmers' access to seed of improved legume varieties through multi-stakeholder platforms. Springer, Singapore

Chichaybelu M, Girma N, Asnake F, Gemechu B, Mekuriaw T, Geleta T, Chiche W, Rubyogo JC, Akpo E, Ojiewo C (this volume) Enhancing chickpea production and productivity through stakeholders' innovation platform approach in Ethiopia. In: Akpo E, Ojiewo CO, Kapran I, Omoigui LO, Diama A, Varshney RK (eds) Enhancing smallholder farmers' access to seed of improved legume varieties through multi-stakeholder platforms. Springer, Singapore

Iorlamen T, Omoigui LO, Kamara AY, Garba U, Iyorkaa N, Ademulegun T, Solomon R (this volume) Developing sustainable cowpea seed systems for smallholder farmers though innovation platforms in Nigeria: experience of TL III Project. In: Akpo E, Ojiewo CO, Kapran I, Omoigui LO, Diama A, Varshney RK (eds) Enhancing smallholder farmers' access to seed of improved legume varieties through multi-stakeholder platforms. Springer, Singapore

Kouyate Z, Dao KM, Togola O, Malle AK, Malle O, Diakite K, Traore A (this volume) Cowpea seed innovation platform: a hope for small seed producers in Mali. In: Akpo E, Ojiewo CO, Kapran I, Omoigui LO, Diama A, Varshney RK (eds) Enhancing smallholder farmers' access to seed of improved legume varieties through multi-stakeholder platforms. Springer, Singapore 
Miningou A, Traoré AS, Akpo E, Kapran I, Zagré BM, Diasso GA, Kienthéga Y, Zoungrana A (this volume) An analysis of groundnut innovation platform achievements in brokering improved varieties to communities in TL III project in Burkina Faso. In: Akpo E, Ojiewo CO, Kapran I, Omoigui LO, Diama A, Varshney RK (eds) Enhancing smallholder farmers' access to seed of improved legume varieties through multi-stakeholder platforms. Springer, Singapore

Mohammed SG, Jibrin JM, Halliru M, Kapran I, Ajeigbe HA (this volume) Impact assessment of developing sustainable and impact-oriented groundnut seed system under the tropical legumes (III) project in Northern Nigeria. In: Akpo E, Ojiewo CO, Kapran I, Omoigui LO, Diama A, Varshney RK (eds) Enhancing smallholder farmers' access to seed of improved legume varieties through multi-stakeholder platforms. Springer, Singapore

Monyo ES, Akpo E, Ojiewo CO, Varshney RK (this volume) A cross-case analysis of innovation platform experiences in seven countries in West and East Africa and South Asia. In: Akpo E, Ojiewo CO, Kapran I, Omoigui LO, Diama A, Varshney RK (eds) Enhancing smallholder farmers' access to seed of improved legume varieties through multi-stakeholder platforms. Springer, Singapore

Puozaa DK, Jinbaani AN, Adogoba DS, Busagri D, Rasheed MA, Issah AR, Oteng-Frimpong $\mathrm{R}$ (this volume) Enhancing access to quality seed of improved groundnut varieties through multi-stakeholder platforms in Northern Ghana. In: Akpo E, Ojiewo CO, Kapran I, Omoigui LO, Diama A, Varshney RK (eds) Enhancing smallholder farmers' access to seed of improved legume varieties through multi-stakeholder platforms. Springer, Singapore

Sah U, Chaturvedi SK, Dixit GP, Singh NP (this volume) Organized farmers towards chickpea seed self-sufficiency in Bundelkhand region of India. In: Akpo E, Ojiewo CO, Kapran I, Omoigui LO, Diama A, Varshney RK (eds) Enhancing smallholder farmers' access to seed of improved legume varieties through multi-stakeholder platforms. Springer, Singapore

Sako D, Traoré M, Doumbia F, Diallo F, Fané M, Kapran I (this volume) Kolokani groundnut innovation platform activities and achievements through TL III project in Mali. In: Akpo E, Ojiewo CO, Kapran I, Omoigui LO, Diama A, Varshney RK (eds) Enhancing smallholder farmers' access to seed of improved legume varieties through multi-stakeholder platforms. Springer, Singapore

Yirzagla J, Atokple IKD, Haruna M, Mohammed AR, Adobaba D, Haruna B, Karikari B (this volume) Impacts of cowpea innovation platforms in sustaining TL III project gains in Ghana. In: Akpo E, Ojiewo CO, Kapran I, Omoigui LO, Diama A, Varshney RK (eds) Enhancing smallholder farmers' access to seed of improved legume varieties through multi-stakeholder platforms. Springer, Singapore

Open Access This chapter is licensed under the terms of the Creative Commons Attribution 4.0 International License (http://creativecommons.org/licenses/by/4.0/), which permits use, sharing, adaptation, distribution and reproduction in any medium or format, as long as you give appropriate credit to the original author(s) and the source, provide a link to the Creative Commons license and indicate if changes were made.

The images or other third party material in this chapter are included in the chapter's Creative Commons license, unless indicated otherwise in a credit line to the material. If material is not included in the chapter's Creative Commons license and your intended use is not permitted by statutory regulation or exceeds the permitted use, you will need to obtain permission directly from the copyright holder. 